\title{
PENGEMBANGAN MEDIA PEMBELAJARAN 3 DIMENSI PADA MATA PELAJARAN MATEMATIKA UNTUK SISWA PENYANDANG TUNAGRAHITA (Studi Kasus: Siswa Kelas D2/Semester 2 SLB C Negeri Singaraja)
}

\author{
Luh Lina Hartariani ${ }^{1)}$, Luh Putu Eka Damayanthi²), I Made Agus Wirawan3), \\ I Made Gede Sunarya ${ }^{4}$ \\ ${ }^{1}$ Fakultas Teknik dan Kejuruan, Universitas Pendidikan Ganesha (penulis 1) \\ email: linahartariani25@gmail.com \\ ${ }^{2}$ Fakultas Teknik dan Kejuruan, Universitas Pendidikan Ganesha (penulis 2) \\ email: ekadamayanthi@undiksha.ac.id \\ ${ }^{3}$ Fakultas Teknik dan Kejuruan, Universitas Pendidikan Ganesha (penulis 3) \\ email: imade.aguswirawan@undiksha.ac.id \\ ${ }^{4}$ Fakultas Teknik dan Kejuruan, Universitas Pendidikan Ganesha (penulis 4) \\ email: sunarya@undiksha.ac.id
}

\begin{abstract}
Abstrak
Penelitian ini bertujuan untuk: (1) mengimplementasikan media pembelajaran animasi 3 dimensi padamata pelajaran matematika untuk siswa penyandang tunagrahita (Studi Kasus: Siswa Kelas D2/Semester 2 SLB.C Negeri Singaraja), (2) mengetahui respon siswa terhadap pengembangan media pembelajaran animasi 3 dimensi pada mata pelajaran matematika untuk siswa penyandang tunagrahita (Studi Kasus: Siswa Kelas D2/Semester 2 SLB.C Negeri Singaraja).

Perancangan media pembelajaran animasi 3 dimensi menggunakan metode pengembangan Research and Development (R\&D) dan model pengembangan ADDIE yang terdiri dari 5 tahapan desain pengembangan. Tahapan-tahapan model ADDIE yaitu analysis, design, development, implementation dan evaluation. Implementasi dari pengembangan media pembelajaran 3 dimensi pada mata pelajaran matematika dilakukan melalui evaluasi sumatif dan evaluasi formatif.Evaluasi sumatif terdiri uji ahli isi, uji ahli desain dan uji ahli media untuk mengetahui kevalidan media pembelajaran serta isi dari media pembelajaran apakah sudah sesuai sehingga media pembelajaran dapat diterapkan. Sedangkan evaluasi formatif terdiri dari uji coba perorangan, kelompok kecil dan uji lapangan dilakukan di kelas yang sama yaitu kelas D2 di SLB.C Negeri Singaraja.

Rata-rata respon siswa terhadap pengembangan animasi 3 dimensi pada mata pelajaran matematika untuk siswa penyandang tunagrahita yaitu 90,7\%. Pengembangan media pembelajaran animasi 3 dimensi pada mata pelajaran matematika untuk siswa penyandang tunagrahita untuk siswa kelas D2 di SLB.C Negeri Singaraja mampu menjadi sumber belajar bagi siswa. Media pembelajaran digunakan sebagai panduan belajar siswa, sehingga dapat meningkatkan konsentrasi dan fokus pada anak serta membantu proses belajar siswa di sekolah. Ini dibuktikan dengan hasil respon siswa yaitu 90,7\% jika dikonversikan kedalam tabel respon siswa termasuk dalam kategori Sangat Baik.
\end{abstract}

Kata kunci: Media Pembelajaran, Mata Pelajaran Matematika, Anak Tunagrahita, Animasi 3 Dimensi

\footnotetext{
Abstract

This Research was aimed to: (1) implement a three-dimensional animation instructional media in mathematics for students with mental retardation (Case Study: Student of D2 class / second semester. SLB.C Negeri Singaraja), (2) determine students' response to the development of instructional media animation $3 \mathrm{D}$ in mathematics for students with mental retardation (Case Study: student of D2 class / Second semester SLB.C Negeri Singaraja).
} 
The design of the 3D animation instructional media used Research and Development (R\&D) and the ADDIE development model that consisted of five stages of design development. The stages of ADDIE development model were analysis, design, development, implementation and evaluation. The implementation of the development of three dimensional instructional media in mathematics was done through summative evaluation and formative evaluation.Summative evaluation consisted of content expert test, design expert test and media expert test to determine the validity of the instructional media and the content of the instructional media whether it is suitable so that instructional media can be applied.While formative evaluation consisted of testing an individual, a small group and a field tests which carried out in the same class, namely the D2 class in SLB.C Negeri Singaraja.

The average of the students' response to the development of three-dimensional animation in mathematics for students with mental retardation was $90.7 \%$. The development of three-dimensional animation instructional media in mathematics for students with mental retardation for D2 class in Singaraja State SLB.C Negeri Singarajawas able to be a source of learning for students. Instructional media were used as a student learning guide, so as to improve concentration and focus on the child and help the students' learning process in the school.This is evidenced by the result of students' response that was $90.7 \%$ if converted into the table the students' response included in the category of Very Good.

Keywords : Learning Media, Mathematics Subject, Sturdent with Mentally Retarded, 3D Animation

\section{PENDAHULUAN}

Pendidikan adalah salah satu usaha sadar untuk mengembangkan Sumber Daya Manusia (SDM), karena tanpa pendidikan manusia tidak bisa memiliki dan mengikuti perkembangan ilmu pengetahuan, teknologi dan seni.Hal ini sesuai dengan (Undang-Undang nomor 20 tahun 2003) tentang Sistem Pendidikan Nasional (Sindiknas) yang menyatakan pendidikan adalah usaha sadar dan terencana untuk mewujudkan suasana belajar dan proses pembelajaran agar peserta didik secara aktif mengembangkan potensi dirinya untuk memiliki kekuatan spiritual keagamaan, pengendalian diri, kepribadian, kecerdasan, akhlak mulia, serta keterampilan yang diperlukan dirinya, masyarakat, bangsa dan Negara.

Sisdiknas terbaru ini memberikan penekanan bahwa penyelenggaraan pendidikan harus dilaksanakan secara demokratis dan berkeadilan serta tidak diskriminatif dengan menjunjung tinggi hak asasi manusia, nilai keagamaan, nilai kultural, dan kemajemukan bangsa. Dengan demikian nampak bahwa semua elemen masyarakat di dunia berhak untuk memperoleh pendidikan, tak terkecuali bagi anak-anak dengan kebutuhan khusus atau sering disebut anak luar biasa.
Menurut Ni Made Suriadi, S.Pd., M.Pd guru kelasD2 SLB.C Negeri Singaraja dampak dari keterbatasan penyandang tunagrahita dalam mengikuti pembelajaran di sekolah yaitu tidak mampunya siswa menyerap pelajaran dengan baik, kurangnya motivasi belajar anak, serta keengganan untuk mengikuti pelajaran sampai selesai sehingga waktu lebih banyak dipakai untuk bermain dan diam.Setiap mata pelajaran menggunakan media pembelajaran visual yang telah ada sebelumnya seperti benda yang berbentuk pola segitiga, persegi panjang, lingkaran, penggaris, papan puzzle, buku-buku, gambar-gambar, serta spidol sudah cukup membantu dalam proses pembelajaran, namun lain halnya dengan mata pelajaran matematika.Kendala dalam proses pembelajaran matematika adalah terbatasnya ketersediaan media yang menjadikan ketidakefektifan proses pembelajaran, rendahnya penguasaan konsep dan pemahaman anak.

Berdasarkan hasil wawancara dengan Ni Made Suriadi, S.Pd., M.Pd, guru kelas D2 SLB.C Negeri Singaraja mengatakan bahwa dalam proses penyampaian materi dengan video animasi/kartun dirasakan lebih kondusif dibandingkan dengan video yang mempergunakan benda asli sebagai 
modelnya karena siswa lebih tertarik dengan bentuk yang variatif dari animasi, segi pewarnaan dan juga tampilan. Penggunaan media pembelajaran animasi juga dapat meningkatkan konsentrasi dan fokus pada anak.

Berdasarkan

pemaparan

permasalahan tersebut, maka penulis memandang perlu mengembangkan topik ini dengan judul "Pengembangan Media Pembelajaran 3 Dimensi Pada Mata Pelajaran Matematika Untuk Siswa Penyandang Tunagrahita (Studi Kasus: Siswa Kelas D2/Semester 2 SLB.C Negeri Singaraja)".

\section{Anak Tunagrahita}

Penyandang tunagrahita merupakan salah satu anak luar biasa yang mempunyai intelegensi serta keterbatasan fungsi kecerdasan intelektual yang berada di bawah usia kronologisnya secara signifikan dan keterbatasan pada keterampilan adaptif yang mencakup area komunikasi, merawat diri, home living, keterampilan sosial, bermasyarakat, mengontrol diri, funcsional academics, waktu luang dan kerja (Somantri, H. T., 2007).

\section{Mata Pelajaran Matematika}

Matematika merupakan mata pelajaran yang bersifat abstrak, sehingga dituntut kemampuan guru untuk dapat mengupayakan metode yang tepat sesuai dengan tingkat perkembangan mental siswa (Pandoyo, 1992).

\section{Pengertian Animasi}

Animasi adalah sebuah proses merekam dan memainkan kembali serangkaian gambar statis untuk mendapatkan sebuah ilusi pergerakan (Ibiz Fernandez McGraw- Hill/Osborn, C., 2002).

\section{Macam-macam Bentuk Animasi}

Terdapat 9 bentuk animasi dalam dunia multimedia yang digunakan untuk menciptakan gerakan pada layer antara lain Cell Animation, Frame Animation, Sprite Animation, Path Animation, Spline Animation, Vector Animation, Character
Animation, Computational Animation, serta Morping.

\section{Kamera} ada:

Bagian-bagian dalam teknik kamera

1. Pembingkaian Kamera (Camera Framing)

2. Sudut Kamera (Camera Angles)

3. Perpindahan Kamera (Camera Movement)

\section{Audio}

Merupakan aplikasi untuk memutar dan mengkonversi suara analog menjadi format digital, yang bisa di dengarkan pada berbagai benda elektronik.

\section{Video}

Merupakan sebuah pergerakan gambar yang konsisten dan telah diatur kecepatan geraknya.

\section{Perangkat Lunak}

Perangkat lunak yang digunakan dalam pengembangan media ini adalah Blender 2.77, Corel Video Studio Pro X4, Cool Edit Pro 2.1, MakeHuman 1.0.2, Adobe Photoshop CS6, AVS Editor Video 7.2, Mixcraft 6.1, dan Smart Voice Recorder by Phone.

\section{Penelitian Pengembangan}

Pengembangan sebagai suatu proses untuk mengembangkan dan memvalidasi produk-produk yang akan digunakan dalam pendidikan dan pembelajaran (Soenarto, 2005).

\section{Media Pembelajaran}

Fungsi media pembelajaran adalah sebagai pembawa informasi dari sumber (guru) menuju penerima (siswa) (Santyasa, 2009).

\section{Desain Pembelajaran}

Merupakan ilmu untuk menciptakan spesifikasi pengembangan, pelaksanaan, penilaian serta pengelolaan situasi yang memberikan fasilitas pelayanan pembelajaran dalam skala makro dan mikro untuk berbagai mata pelajaran pada berbagai tingkatan kompleksitas. 


\section{METODE}

\section{Analisis Masalah dan Solusi}

Pada tahap analisis masalah,
penulismelakukan penelitian dan
pencarian informasi terkait media
pembelajaran animasi 3 dimensi.Penulis
menemukan bahwa anak tunagrahita
memiliki kemampuan daya fikir yang
lambat dan terbatas serta pembosan dan
mudah beralih perhatian sehingga kurang
memiliki kreativitas dan keterampilan.

Dampak dari keterbatasan penyandang tunagrahita dalam mengikuti pembelajaran di sekolah yaitu tidak mampunya siswa menyerap pelajaran dengan baik, kurangnya motivasi belajar anak, serta keengganan untuk mengikuti pelajaran sampai selesai sehingga waktu lebih banyak dipakai untuk bermain ataupun diam. Setiap mata pelajaran menggunakan media pembelajaran visual yang telah ada sebelumnya seperti benda yang berbentuk pola segitiga, persegi panjang, lingkaran, penggaris, papan puzzle, gambar-gambar serta buku-buku sudah cukup membantu dalam proses pembelajaran. Berbeda dengan mata pelajaran matematika. Kendala dalam proses pembelajaran matematika adalah terbatasnya ketersediaan media yang menjadikan ketidakefektifan proses pembelajaran, rendahnya penguasaan konsep dan pemahaman anak.

Berdasarkan wawancara dengan $\mathrm{Ni}$ Made Suriadi, S.Pd., M.Pd, guru kelas D2 SLB.C Negeri Singaraja menyatakan bahwa penyandang tunagrahita lebih tertarik kepada penyampaian materi dengan menggunakan media pembelajaran yang bersifat animasi dibandingkan dengan video yang mempergunakan benda asli sebagai modelnya. Guru sudah pernah memberi perlakuan (treatment) kepada siswa kelas D2 video animasi dimensi seperti upin ipin dan dora. Siswa sangat senang dan lebih memusatkan perhatian hanya saja video yang diberikan tidak dapat diterima seutuhnya oleh siswa, karena terlalu cepat pengucapannya dan bahasanya susah dimengerti. Materi yang diberikan juga tidak sesuai silabus dari sekolah.

$\begin{array}{cr}\text { Berdasarkan } & \text { pemaparan } \\ \text { permasalahan } & \text { tersebut, }\end{array}$

berkeinginan untuk mengembangkan sebuah media berbasis komputer atau bisa disebut juga media pembelajaran. Media pembelajaran yang penulis kembangkan adalah media pembelajaran 3 dimensi dalam bentuk penelitian yang berjudul "Pengembangan Media Pembelajaran 3 Dimensi Pada Mata Pelajaran Matematika Untuk Siswa Penyandang Tunagrahita (Studi Kasus: Siswa Kelas D2/Semester 2 SLB.C Negeri Singaraja)".

\section{Metode Penelitian}

1. Rancangan Penelitian

Jenis penelitian yang dilaksanakan adalah Penelitian dan Pengembangan (Research and Development / R\&D).Penelitian dan Pengembangan adalah metode penelitian yang digunakan untuk menghasilkan produk tertentu atau mengembangkan produk yang telah ada serta menguji keefektifan produk tersebut.

2. Model Pengembangan

Model pengembangan dalam penelitian ini menggunakan model ADDIE.Tahapan-tahapan pengembangan pembelajaran sebagai berikut:

a. Analysis (Analisis) yaitu melakukan analisis kebutuhan, mengidentifikasi masalah (kebutuhan) di SLB.C Negeri Singaraja. Dalam kegiatan analisis kebutuhan dilakukan analisis terhadap silabus yang meliputi SK-KD, karakteristik siswa, bahan ajar/media yang telah digunakan untuk memperoleh informasi media yang dibutuhkan oleh peserta didik dalam mempelajari kompetensi yang telah diprogramkan.

b. Design (Desain) media dilakukan dengan menyusun buram media. Pengembangan media diawali dengan menyusun buram media. Media yang dihasilkan dinyatakan sebagai buram sampai dengan selesainya proses validasi dan uji coba.

Tahap desain merupakan langkah awal dalam pembuatan animasi 3D dan harus mempersiapkan segala sesuatu yang akan dibutuhkan antara lain penulisan cerita dan 


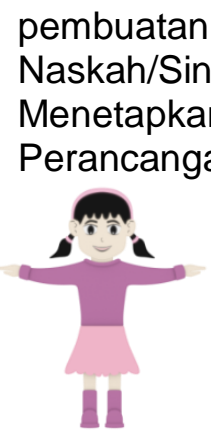

a

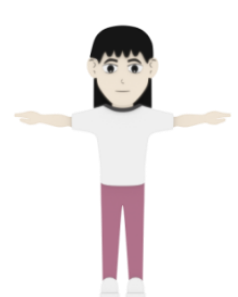

C desain,

Penulisan Ide Cerita, opsis, ormat Output, dan an Karakter.
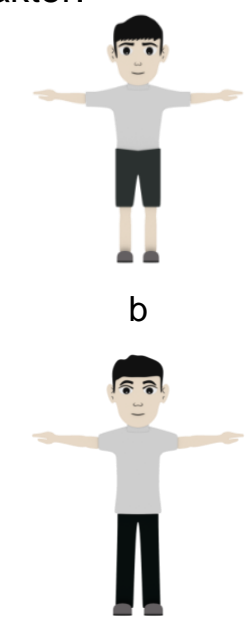

d

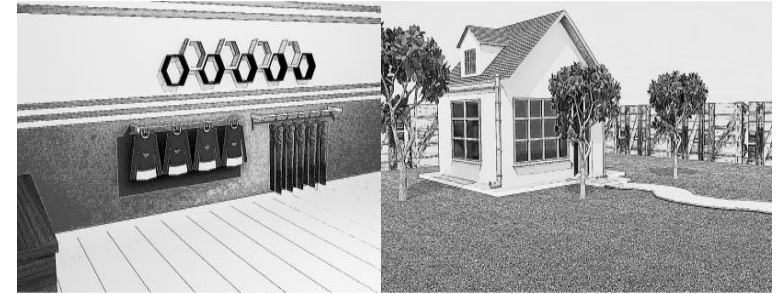

Gambar 8. Toko Pakaian

Gambar 9. Halaman Rumah Bimo

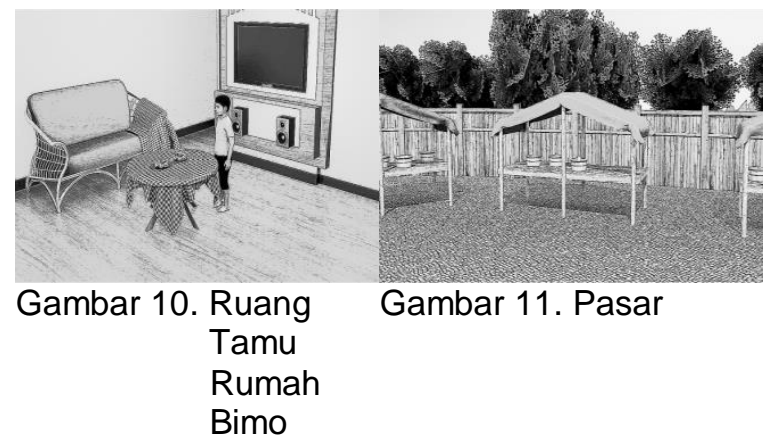

Gambar 1. Karakter Animasi 2D (a. Lyli, b. Bimo, c. Bibi, d. Paman)

\section{Perancangan Gambar Pendukung}

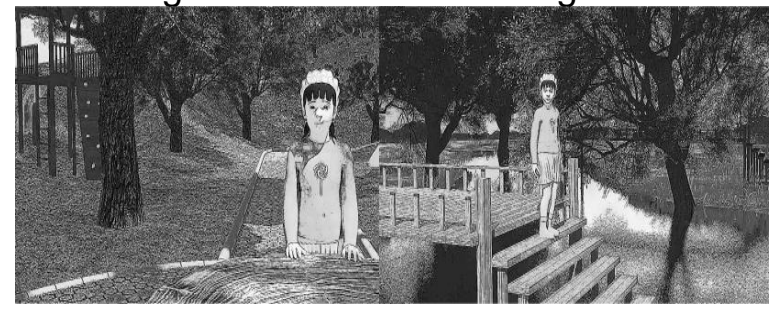

Gambar 2. Taman Gambar 3. Jembatan di Atas Sungai
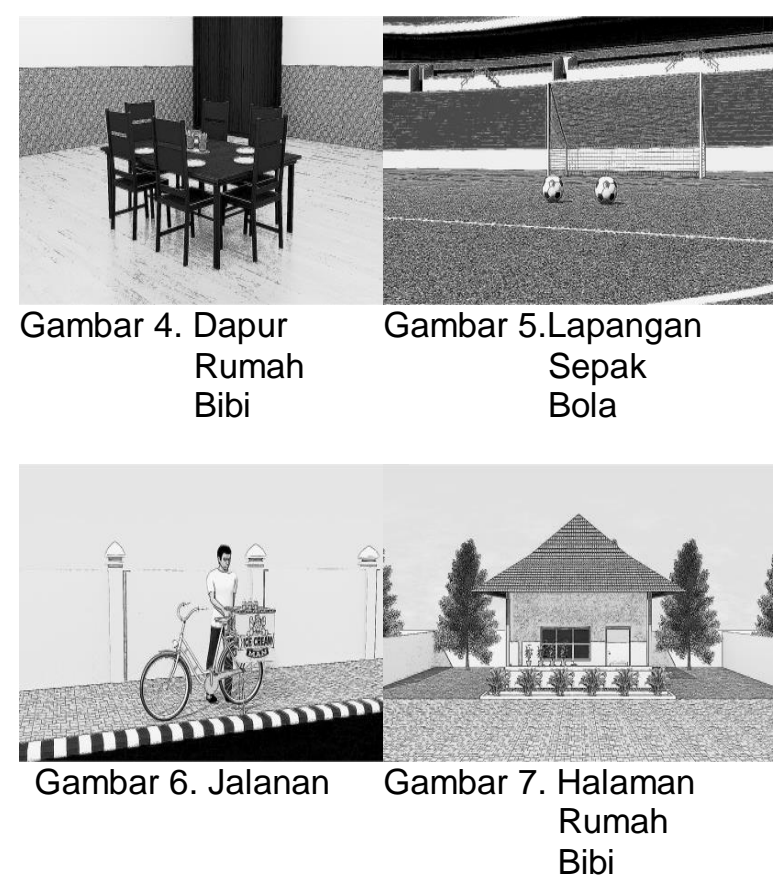

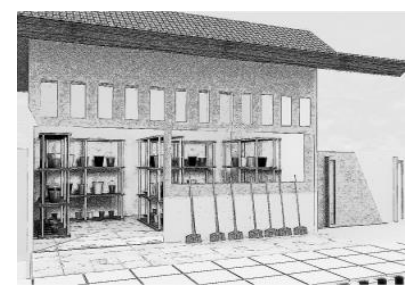

Gambar 12.Toko

Bangunan

c. Development (Pengembangan) merupakan proses untuk mewujudkan rancangan tersebut menjadi kenyataan. Adapun bentuk dari media yang digunakan adalah dalam bentuk film animasi 3 dimensi. Hasil dari tahap ini adalah sebuah produk yaitu berupa media pembelajaran animasi 3D yang sudah terstruktur sesuai dengan standar kompetensi, kompetensi dasar dan indikator dimana ketiganya sudah termuat dalam setiap uraian materi.

Pada tahap pengembangan ini animasi dibuat sesuai kebutuhan dari tahap pengembangan yang telah dirancang, seperti: Modelling, Texturing, Ringging, Skining, Acting/Animation, Lighting, Rendering, Tahap Perekaman, dan Tahap Penggabungan.

d. Implementation (Implementasi) merupakan tahap uji coba atau menerapkan media pembelajaran kepada siswa kelas D2 di SLB.C Negeri Singaraja. Tahap ini dilakukan untuk 
mengetahui kesesuaian/validitas media terhadap materi pelajaran.

e. Evaluation (Evaluasi) merupakan tahap untuk melihat keberhasilan dari media pembelajaran yang dikembangkan apakah sesuai dengan harapan semula. Evaluasi bertujuan untuk melakukan penyempurnaan terhadap media pembelajaran yang telah dikembangkan.

\section{HASIL DAN PEMBAHASAN Implementasi Media Pembelajaran Animasi 3 Dimensi}

Pada tahap implementasi ini akan dipaparkan hal-hal yang berkaitan dengan implementasi media pembelajaran animasi 3 dimensi pada mata pelajaran matematika untuk siswa penyandang tunagrahita (Studi Kasus: Siswa Kelas D2/Semester 2 SLB.C Negeri Singaraja)yang terdiri dari lingkup implementasi perangkat lunak dan perangkat keras, implementasi pra produksi, implementasi produksi dan implementasi pasca produksi.

1. Lingkungan Implementasi Media Pembelajaran Animasi 3 Dimensi

a. Spesifikasi Perangkat Lunak

Perangkat lunak yang digunakan untuk mengimplementasikan media pembelajaran animasi 3 dimensi pada mata pelajaran matematika untuk siswa penyandang tunagrahita (Studi Kasus: Siswa Kelas D2/Semester 2 SLB.C Negeri Singaraja) yaitu Sistem Operasi Microsoft Windows7 Ultimate, Blender 2.77, Corel Video Studio Pro X4, Cool Edit Pro 2.1, MakeHuman 1.0.2, Adobe Photoshop CS6, AVS Video Editor 7.2, dan Mixcraft 6.1.

b. Spesifikasi Perangkat Keras Perangkat keras yang digunakan untuk mengimplementasikan film animasi 3 dimensi yaitu Personal Computer, HP Pavilion p6-2343I, Intel ${ }^{\circledR}$ Core ${ }^{\mathrm{TM}}$ i3-2600K Quard-Core Processor $3.30 \mathrm{GHz}$, RAM $8.00 \mathrm{~GB}$ DDR3, Harddisk 2000 GB/ 1 TB, Dilengkapi alat input dan output.

2. Implementasi Tahap Desain

Pada tahap implementasi tahap desainakan dipaparkan mengenai implementasi karakter, implementasi gambar pendukung, dan implementasi storyboard. Tampilan-tampilan dari setiap implementasi media pembelajaran animasi 3 dimensi pada mata pelajaran matematika untuk siswa penyandang tunagrahita (Studi Kasus: Siswa Kelas D2/Semester 2 SLB.C Negeri Singaraja) yaitu sebagai berikut:

a. Implementasi Karakter

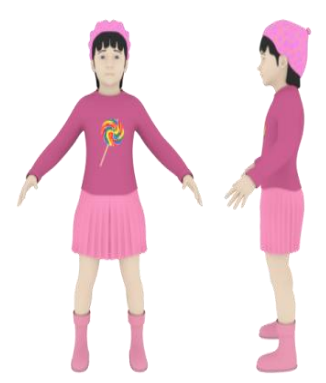

a

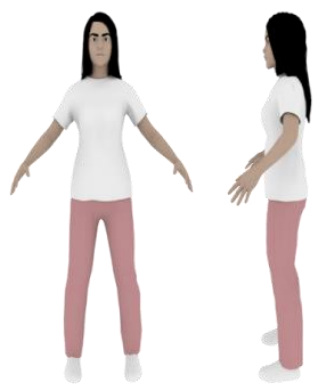

c

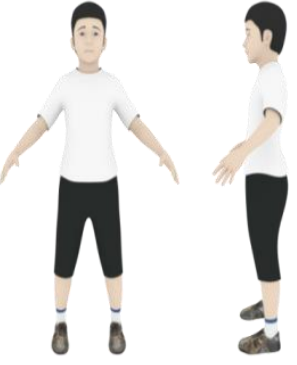

b

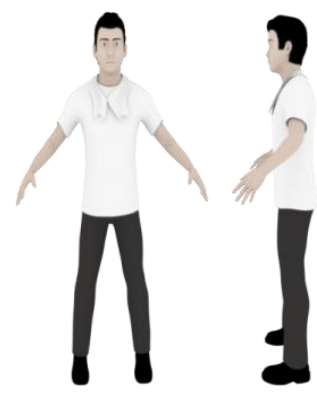

d
Gambar 13. Karakter Animasi 3D (a. Lyli, b. Bimo, c. Bibi, d. Paman)

b. Implementasi Gambar Pendukung

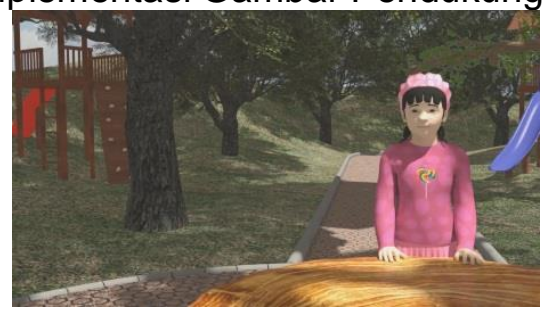

Gambar 14. Taman

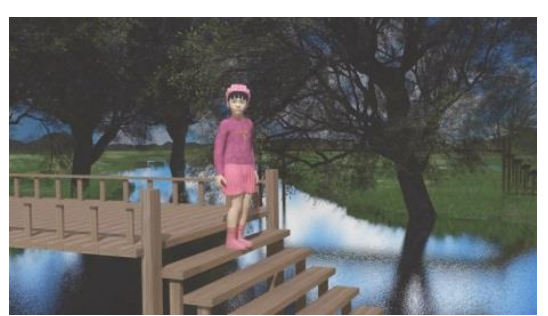

Gambar 15. Jembatan di Atas Sungai 


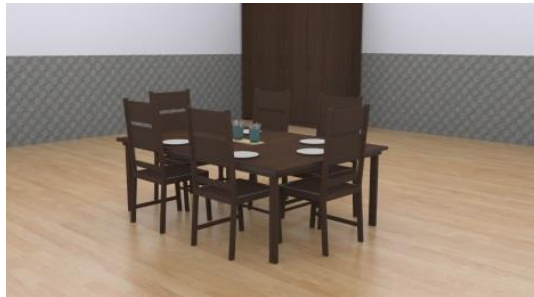

Gambar 16. Dapur Rumah Bibi

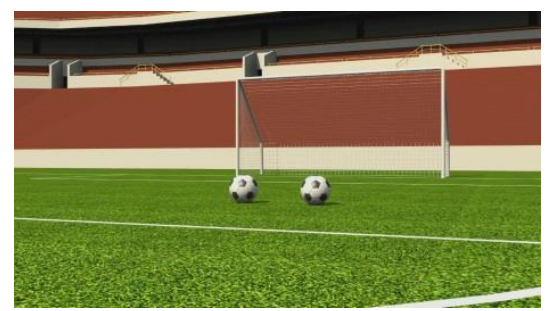

Gambar 17. Lapangan Sepak Bola

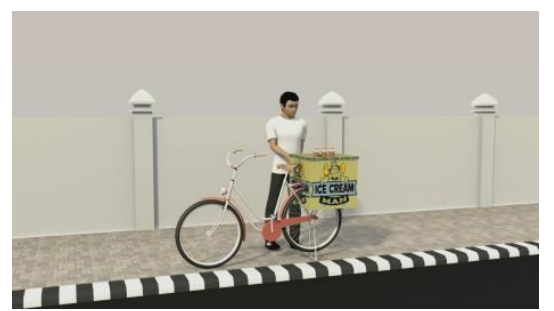

Gambar 18. Jalanan

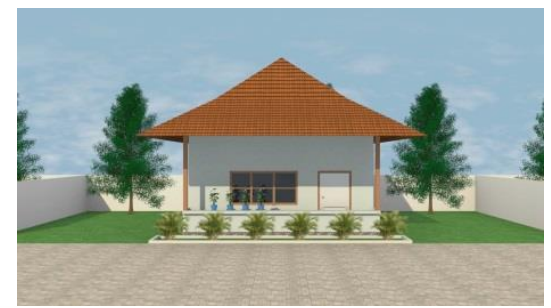

Gambar 19. Halaman Rumah Bibi

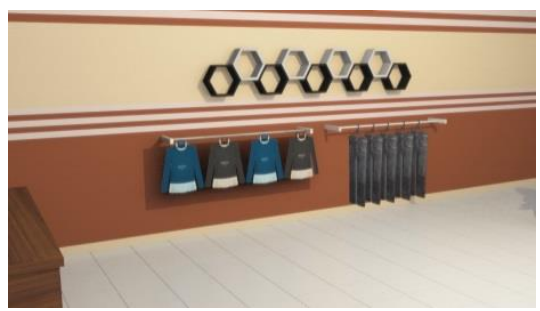

Gambar 20. Toko Pakaian

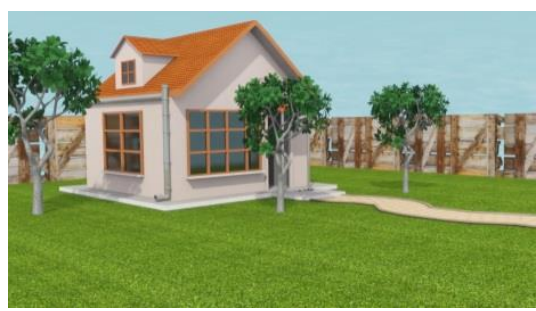

Gambar 21. Halaman Rumah Bimo

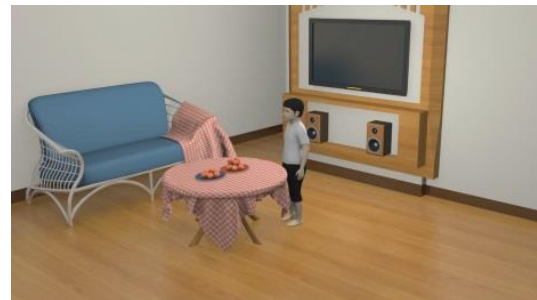

Gambar 22. Ruang Tamu Rumah Bimo

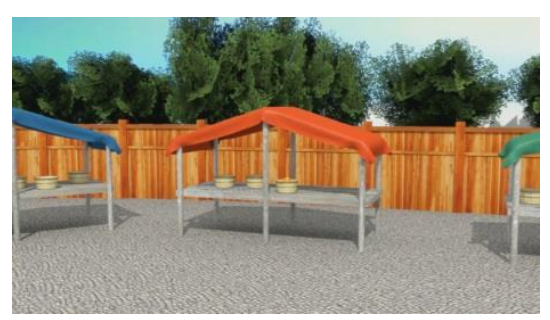

Gambar 23. Pasar

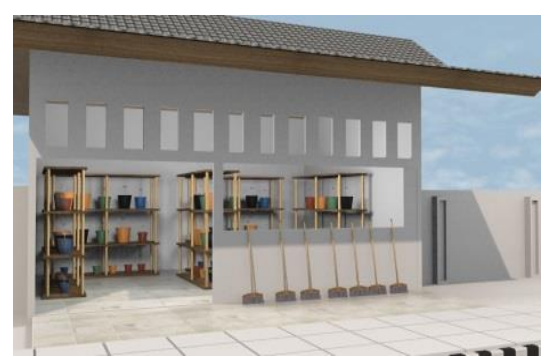

Gambar 24. Toko Bangunan

c. Implementasi Storyboard Media Pembelajaran Animasi 3 Dimensi

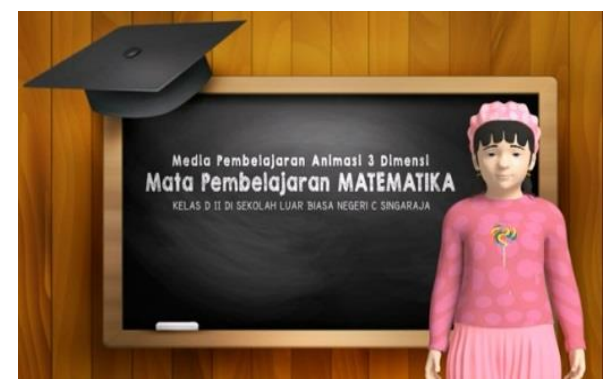

Gambar 25. Implementasi Tampilan Judul Media Pembelajaran 


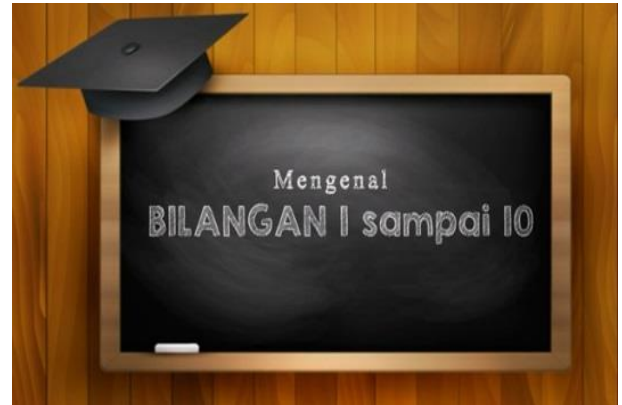

Gambar 26. Implementasi Tampilan Judul Mengenal Bilangan 1 Sampai 10

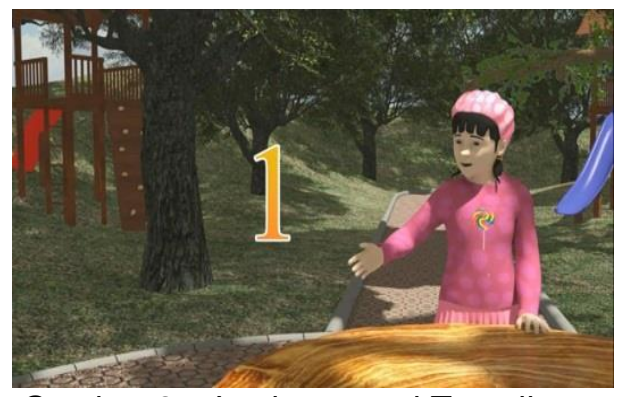

Gambar 27. Implementasi Tampilan Memperkenalkan Bilangan 1

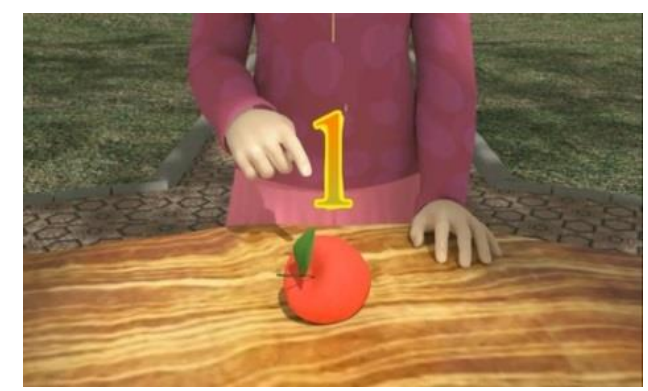

Gambar 28. Implementasi Tampilan Lyli Memperkenalkan Bilangan 1 dengan Contoh Benda

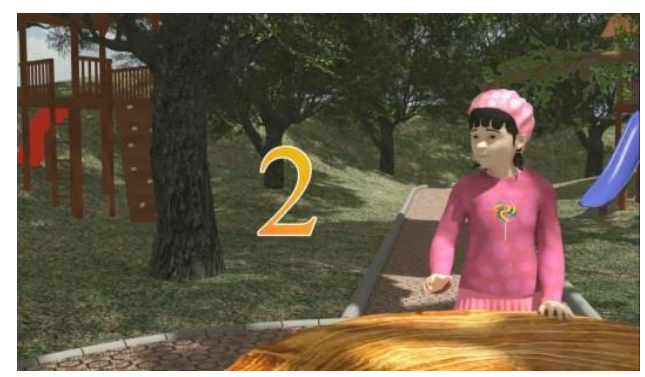

Gambar 29. Implementasi Tampilan Lyli Memperkenalkan Bilangan 2
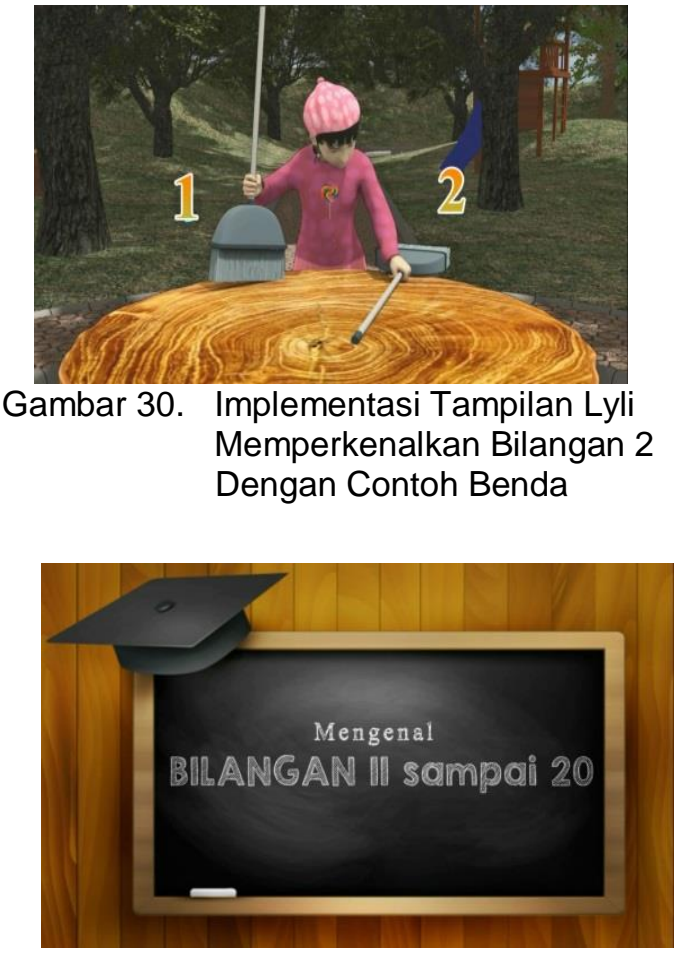

Gambar 31. Implementasi Tampilan Judul Mengenal Bilangan 11 Sampai 20

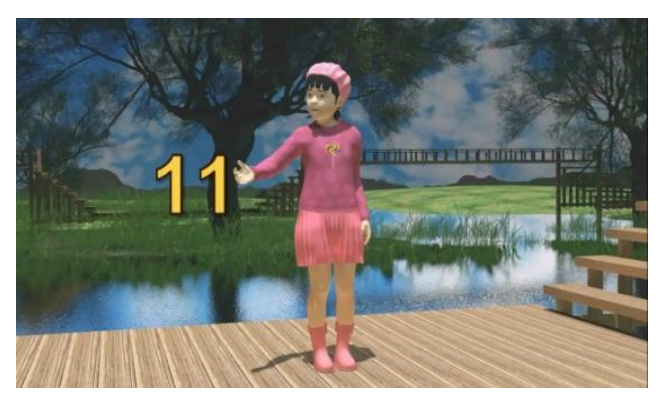

Gambar 32. Implementasi Tampilan Lyli Memperkenalkan Bilangan 11 


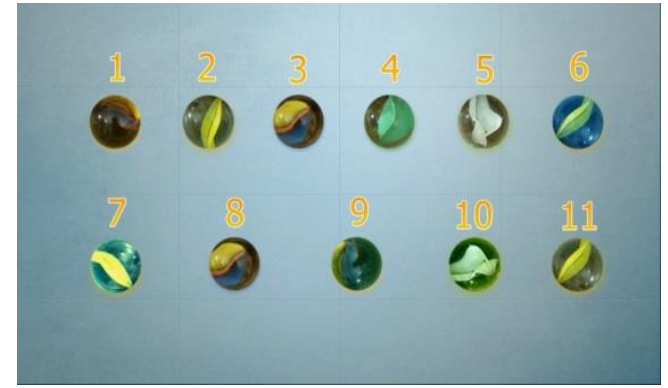

Gambar 33. Implementasi Tampilan Lyli Memperkenalkan Bilangan 11 Dengan Contoh Benda

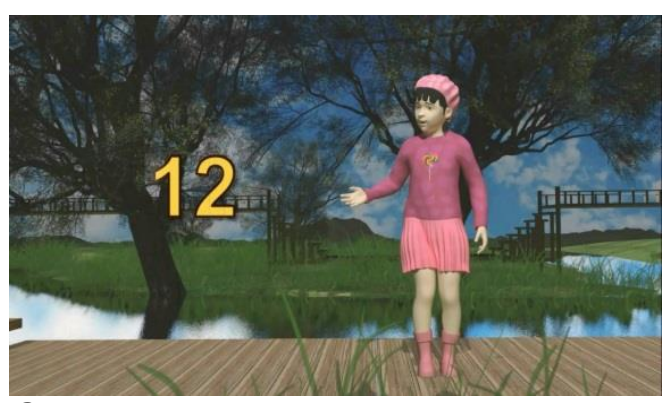

Gambar 34. Implementasi Tampilan Lyli Memperkenalkan Bilangan 12

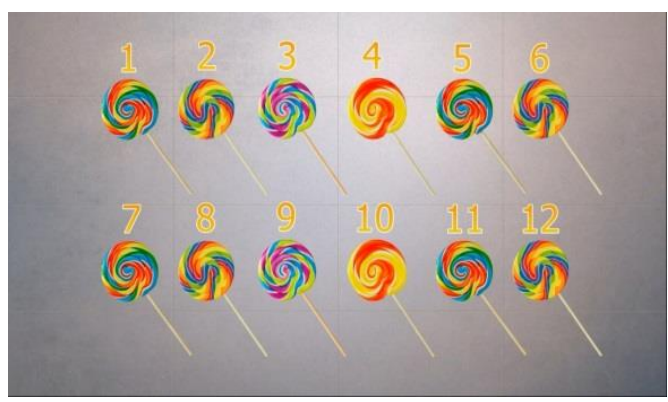

Gambar 35. Implementasi Tampilan Lyli Memperkenalkan Bilangan 12 Dengan Contoh Benda

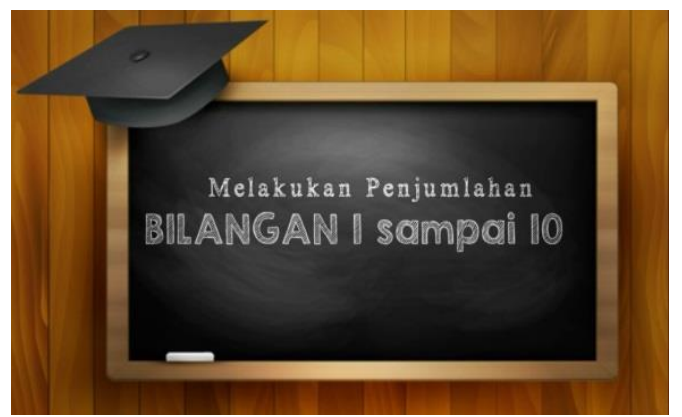

Gambar 36. Implementasi Tampilan Judul Melakukan Penjumlahan Bilangan 1 Sampai 10

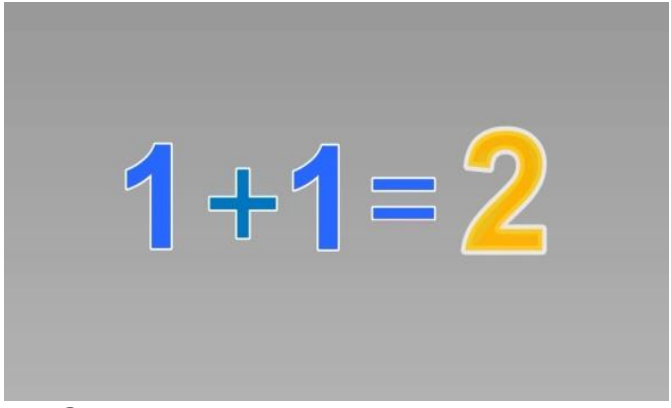

Gambar 37. Implementasi Tampilan Melakukan Penjumlahan Bilangan 2
Fase 1

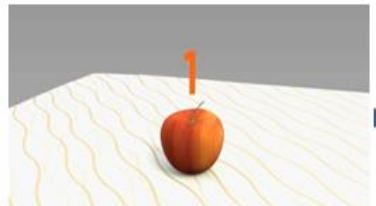

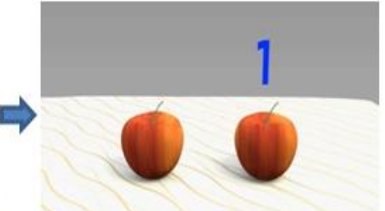

Fase 2

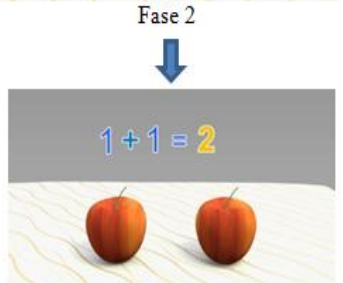

Fase 3
Gambar 38. Implementasi Tampilan Melakukan Penjumlahan Bilangan 2 Dengan Contoh Benda

Berdasarkan Gambar 38, pada fase 1 akan muncul satu buah apel dengan durasi 20 detik kemudian muncul lagi satu buah apel pada fase 2. Lalu pada fase 3 akan muncul dua buah apel beserta teks penjumlahan. 


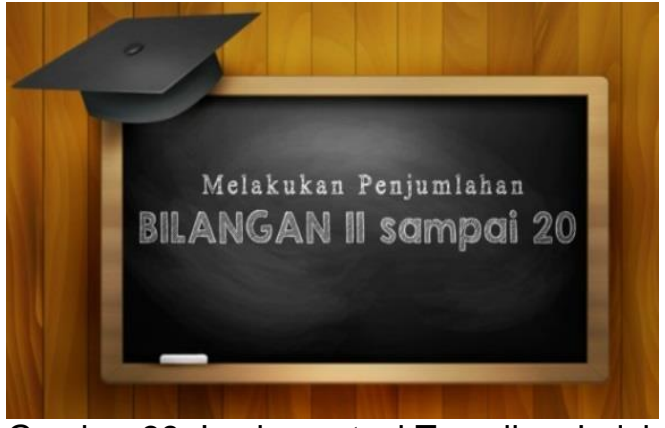

Gambar 39. Implementasi Tampilan Judul Melakukan Penjumlahan Bilangan 11 Sampai 20

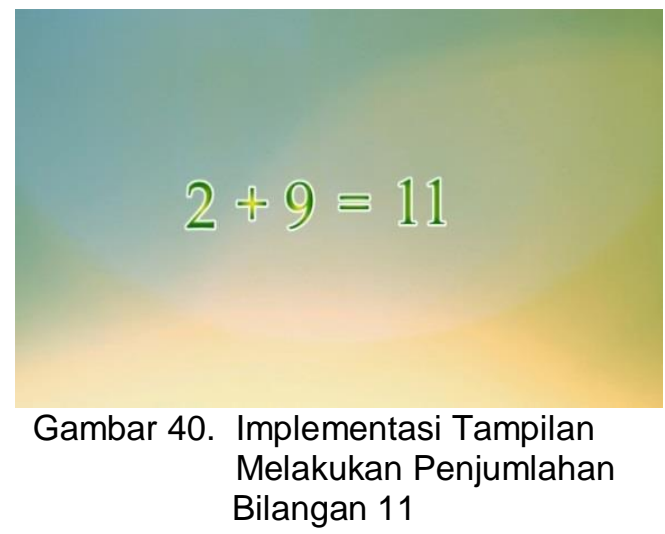

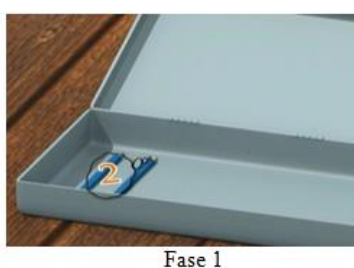

Fase 1

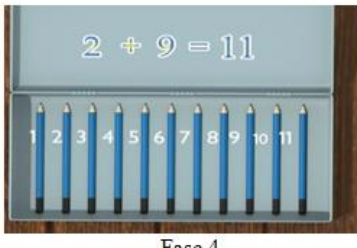

Fase 4

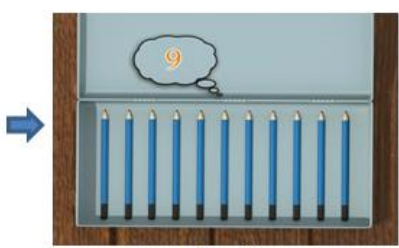

Fase 2

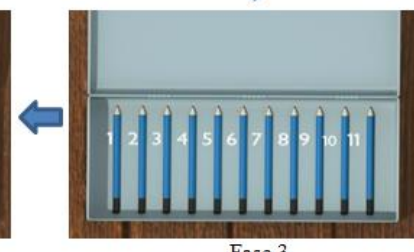

Fase 3
Gambar 41. Implementasi Tampilan Melakukan Penjumlahan Bilangan 11 Dengan Contoh Benda

Berdasarkan Gambar 41, pada fase 1 akan muncul dua buah pensil dalam kotak pensil dengan durasi 20 detik kemudian muncul lagi sebelas buah pensil pada fase 2 . Lalu pada fase 3 akan muncul sebelas buah pensil dan melakukan perhitungan satu per satu. Pada fase 4 akan muncul teks penjumlahan.

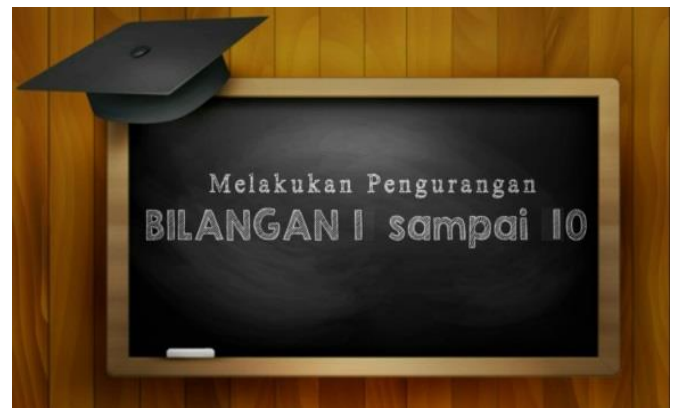

Gambar 42. Implementasi Tampilan Judul Melakukan Pengurangan Bilangan 1 Sampai 10

$$
5-4=1
$$

Gambar 43. Implementasi Tampilan Melakukan Pengurangan Bilangan 1

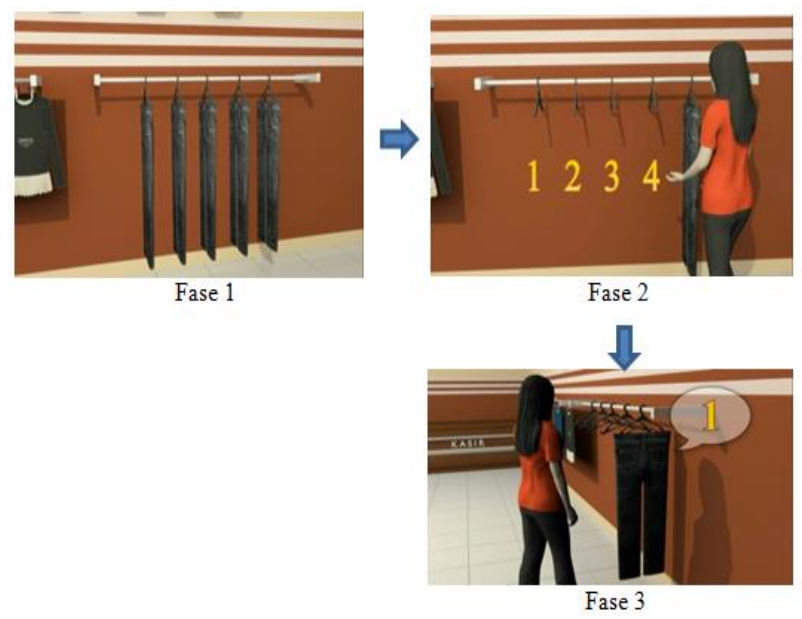

Gambar 44. Implementasi Tampilan Melakukan Pengurangan Bilangan 1 Dengan Contoh Benda

Berdasarkan Gambar 44, pada fase 1 akan muncul lima buah celana yang digantung di tembok kemudian pada fase 2 datang bibi yang membeli empat buah celana. Lalu pada fase 3 akan muncul sisa celana yang telah di beli bibi.

\section{SIMPULAN DAN SARAN}


Berdasarkan paparan hasil
penelitian dan pengembangan dapat disimpulkan sebagai berikut.

1. Rancangan media pembelajaran 3 dimensi pada mata pelajaran matematika menggunakan model pengembangan ADDIE dengan lima tahapan yaitu analysis, degisn, development, implementation dan evaluation. Implementasi dari pengembangan media pembelajaran 3 dimensi pada mata pelajaran matematika dilakukan melalui evaluasi sumatif dan evaluasi formatif. Evaluasi sumatif terdiri uji ahli isi, uji ahli desain dan uji ahli media untuk mengetahui kevalidan media pembelajaran serta isi dari media pembelajaran apakah sudah sesuai sehingga media pembelajaran dapat diterapkan. Sedangkan evaluasi formatif terdiri dari uji coba perorangan, kelompok kecil dan uji lapangan dilakukan di kelas yang sama yaitu kelas D2 di SLB.C Negeri Singaraja.

2. Rata-rata respon siswa terhadap pengembangan animasi 3 dimensi pada mata pelajaran matematika untuk siswa penyandang tunagrahita yaitu 90,7\%. Pengembangan media pembelajaran animasi 3 dimensi pada mata pelajaran matematika untuk siswa penyandang tunagrahita untuk siswa kelas D2 di SLB.C Negeri Singaraja mampu menjadi sumber belajar bagi siswa. Media pembelajaran digunakan sebagai panduan belajar siswa, sehingga dapat meningkatkan konsentrasi dan fokus pada anak serta membantu proses belajar siswa di sekolah. Ini dibuktikan dengan hasil respon siswa yaitu $90,7 \%$ jika dikonversikan kedalam tabel respon siswa termasuk dalam kategori Sangat Baik.

\section{DAFTAR PUSTAKA}

Undang-Undang nomor 20 tahun 2003. (n.d.). Sistem Pendidikan Nasional (Sindiknas).

Somantri, H. T. (2007). Psikologi anak luar biasa. Bandung: Refika Aditama.
Pandoyo. (1992). In Strategi Belajar Mengajar. Semarang: IKIP Semarang Press.

Ibiz Fernandez McGraw- Hill/Osborn, C. (2002). Macromedia Flash Animation \& Cartooning: A creative Guide.

Soenarto. (2005, Agustus). Metodologi Penelitian Pengembangan untuk Peningkatan Kualitas Pembelajaran (research Methodology to The Improvent Of Instruction)". Makalah Disampaikan pada Pelatihan Nasional Penelitian Peningkatan Kualitas Pembelajaran dan Penelitian Tindakan Kelas (PPKP dan PTK) Bagi Dosen LPTK.

Santyasa. (2009). Metode Penelitian Pengembangan Teori Pengembangan Media. Retrieved Maret 26, 2015, from http://www.freewebs.com/santyasa/p df2/METODE_PENELITIAN.pdf 